\title{
Ethics in Public Relations and Responsible Advocacy Theory
}

\author{
MD SHAHIDUL HAQUE \\ University of Chittagong, Bangladesh \\ shahidjr@yahoo.com \\ JAMILAH AHMAD \\ Universiti Sains Malaysia \\ jahmad@usm.my
}

\begin{abstract}
Ethics in public relations plays a vital role in human communication. It brings the credibility to organizations. It helps to establish faithful relationship between organizations and the public. Excellence in public relations can be achieved by ethical practices. Public relations organizations should follow code of ethics to provide reliable services to the target audience. Organizations need to ensure that the codes of ethics are practically implemented for the betterment of all the stakeholders. The responsible advocacy theory is one of the latest theories of ethics in public relations. It focuses on the responsibilities of public relations practitioners. It is based on three major principles of public relations ethics: the comparison of harms and benefits, respect of persons, and distributive justice. It encourages to avoid all harmful contents, guarantee the public interest, safeguard the human dignity and maintain justice in communication. This article highlights on the basic concepts of ethics in public relations, codes of ethics in different public relations organizations and key points of responsible advocacy theory.
\end{abstract}

Keywords: Ethics, Public Relations, Responsible Advocacy Theory.

\section{INTRODUCTION}

Ethics is a big concern and important discourse in all sections of society (Seib \& Fitzpatrick, 2006). Ethics in public relations has received different degrees of attention from scholars since the period of Lee and Berneys (Edgett, 2002). The agreement has been established in public relations research for many years that ethics must be central to professional practice (Walle, 2003). Grunig, Grunig, and Dozier (2002) identified ethics as the $10^{\text {th }}$ principle of public relations excellence. When ethics and responsibility are guaranteed in public relations, it offers a significant communication role for organizations, nations and even the world (Grunig, 1993).

Some researchers and experts consider persuasion as the heart of public relations work. Kruckeberg and Starck (1988) mentioned that persuasion and advocacy are commonly accepted by public relations practitioners as their main functions. Other opine that modern public relations does not focus only on persuasion. They think that it serves both the organizations and their public (Grunig, 1992). The ethical public relations ensures the welfare of all stakeholders. Murphy (1991) accepted both of these opinions saying that the modern public relations combines both self-interested persuasive tactics as well as sincere caring initiatives. According to him, the practices of this combined efforts are higher than the public relations activities for the benefits of the organizations only. Public relations practitioners uphold shared understanding and peaceful coexistence among individuals and organizations (Seib \& Fitzpatrick, 2006). 


\section{ETHICS IN PUBLIC RELATIONS}

Ethics is a value system that tells "what is right or wrong, fair or unfair, just or unjust" (Parsons, 2004). It is the process of making correct decisions on the basis of valid reasons (Tuffley, 2004). "There are two aspects to ethics: The first involves the ability to discern right from wrong, good from evil and propriety from impropriety. The second involves the commitment to do what is right, good and proper. Ethics entails action; it is not just a topic to mull or debate" (Josephson, 2001). Amila (2016) mentioned six pillars of ethics as following:

- Trustworthiness (Honesty, Integrity, Reliability/Promise-keeping, Loyalty)

- Respect (Civility, Courtesy and Decency, Dignity and Autonomy, Tolerance and Acceptance)

- Responsibility (Accountability, Pursuit of Excellence, Self-Restraint)

- Fairness (Process, Impartiality, Equity)

- Caring

- Citizenship

Ethics determines the behaviour of the people. It plays different roles in different parts of human life. Personal ethics determines personal behavior and professional ethics determines the behaviour of the practitioners in various professions (Haque \& Ahmad, 2016). Ethics is a basic part of public relations. It includes honesty, openness, loyalty, fairmindedness, respect, integrity, and forthright communication (Parsons, 2004). Baker and Martinson (2002) presented the 'TARES Test' which consists of five principles for ethical advocacy such as truthfulness, authenticity, respect, equity, and social responsibility (Syed Arabi, 2016).

Six major issues are addressed in the codes of public relations: (1) work environment (including the notions of team work, service, partnerships, creativity, and challenge), (2) goals (including the notions of growth, results, excellence, and social responsibility), (3) behaviour (including the notions of honesty, fairness, openness, and honor), (4) professionalism (including the notions of accountability, responsibility, dedication, and hard work), (5) fulfillment (including the notions of balance, fun, and recognition) and (6) respect (including the notions of respect for the firm, coworkers, clients, and society) (Jung Ki \& Yeon Kim, 2010).

\section{CODE OF ETHICS IN PUBLIC RELATIONS ORGANIZATIONS}

Public relations practitioners must cautiously follow ethical codes to develop public trust of an organization. The Code of Ethics and Code of Professional Conduct are recognized as a basic part of the public relations profession by public relations organizations globally. Codes of ethics are also familiar as codes of practices, codes of conduct, mission statements, or value statements. There are three goals of an Ethical Code: 1) prevent the exploitation of the client, 2) serve the public good, and 3) preserve the integrity of the profession (Scopacasa, 2016). Codes of conduct of any organization should contain the following objectives: (a) to express best ethical practices, (b) to articulate a specific value system that concisely delineates both decisional and behavioral rules, (c) to apply ethical conduct through leadership, (d) the requirement of staff participation, and (e) to accept and guide ethical behavior with incentives that motivate staff members (Fisher, 2013).

Most modern and professional organizations offer different Code of Ethics and Professional Conduct. The law does not force to implement ethical practices and professional conduct, but the members of the organizations are supposed to abide by the 
proposed ethics and professional conduct to protect their own benefits and the overall image of the profession.

\section{IPRM CODE OF PROFESSIONAL CONDUCT}

In Malaysia, the Institute of Public Relations Malaysia presented an official Code of Ethics and Code of Professional Conduct that set the standards for ethical and professional practice for its members and also as a guideline for the industry (Jalil, 2009). Reputation is very important in public relations. The IPRM presented some principles to strengthen the relationship between its members and the people to whom the public relations practitioners are responsible. Some of the ethical principles are respect for the public interest, dealing fairly and honestly, avoiding false or misleading information, maintaining high standards of truth, accuracy and good taste, not to be engaged in any practice which tends to corrupt the integrity of channels of public communication, not to use any organization to promote a special or private interest, not to disclose any confidential information, not to represent conflicting or competing interests, not to advertise to attract business unfairly, not to injure the professional reputation or practice of another member, and not to be engaged in any occupation or business contradictory to the institute (Idid, 2005; Hamdan, 2016).

Kaur and Shaari (2003) did not find very encouraging findings in their research on codes of ethics practiced in the mass communication industry in Malaysia. Firstly, though media practitioners are conscious of ethical principles, there is still a substantial scope of improvement for the practice of ethics. They found that media practitioners' awareness of their respective code of ethics is only average. Secondly, research also shows that among media practitioners, loyalty to the code of ethics is just a little more than average. Several practitioners had said that codes are a good guide for junior communication practitioners. However, abiding by organizational or professional codes should be customary in the life of every working individual, regardless of age (Shaari \& Kaur, 2012). Based on the findings of Abdullah and Threadgold (2008), many codes of ethics have been set in Malaysia by regulatory organizations; yet they are merely seen as 'cosmetic' because there seems to be no enforcement being executed. The practitioners who are not members in any public relations organization are not bound to follow the code of ethics and membership is also not mandatory for practitioners to be in practice. So, the code of ethics has not been enforced among the practitioners (Idid \& Arandas, 2016).

\section{MIDDLE EAST PUBLIC RELATIONS ASSOCIATION (MEPRA)}

Middle East Public Relations Association's (MEPRA) Individual Code of Conduct includes Advocacy and Honesty, Balancing Openness and Privacy, Conflicts of Interest, Law Abiding \& Professionalism and Registered Agency Code of Practice covers five major areas: 1 . General 2. Conduct towards the public, the media and other professionals 3. Conduct towards clients 4. Conduct towards colleagues 5. Discriminatory conduct (King, 2012). All the members (either individual or agency) have to sign up and abide by the codes. This code doesn't present the cultural differences of Arab society that influence public relations in Middle Eastern countries. 


\section{PUBLIC RELATIONS SOCIETY OF AMERICA (PRSA)}

Public Relations Society of America (PRSA), the world's largest public relations organization has the most detailed and inclusive Code of Ethics in the area of public relations (Lattimore, Baskin, Suzette, Toth, \& Van Leuven, 2004). PRSA (2016) mentioned, "The Code is designed to be a useful guide for PRSA members as they carry out their ethical responsibilities. This document is designed to anticipate and accommodate, by precedent, ethical challenges that may arise". It includes Advocacy, Honesty, Expertise, Independence, Loyalty, and Fairness (PRSA, 2016). Providing accurate and truthful information is an obligation to PRSA members to serve the interest of the people and help them to decide appropriately on the basis of correct information (Scopacasa, 2016).

\section{INTERNATIONAL ASSOCIATION OF BUSINESS COMMUNICATORS (IABC)}

The International Association of Business Communicators (IABC) Code of Ethics for Professional Communicators "serves as a guide to making consistent, responsible, ethical and legal choices' in all its communications" (IABC, 2016). It includes honesty, accuracy, obedience to laws and public policy, protection of confidential information, support to ideals of freedom of speech and assembly, being sensitive to others' cultural values and beliefs, giving credit to others for their work, not representing conflicting or competing interests, and not accepting undisclosed gifts or payments for professional services from anyone other than a client or employer.

\section{PRCA PROFESSIONAL CHARTER AND CODES OF CONDUCT}

The Public Relations and Communications Association (PRCA), UK (2016) mentioned the professional charter and codes of conduct in its website as following:

1. Conduct in relation to the PRCA Professional Charter (observe the highest standards, adhere to this code, uphold it and co-operate with fellow members)

2. Conduct towards the Public, the Media and other Professionals (proper regard to the public interest, positive duty to respect the truth, honour to confidences)

3. Conduct towards Colleagues (adhere to the highest standards of accuracy and truth, avoid extravagant claims or unfair comparisons and give credit for ideas and words borrowed from others)

4. Discriminatory Conduct (no discrimination to gender, race, religion, disability or any other).

Bowen (2007) identified some problems regarding the codes of ethics such as lacking of some essential components in the codes, being internally inconsistent, being unclear to implement practically, lack of presenting specific guidance, looking at a code of ethics once and not reading it again, providing no enforcement to monitor the violation, leaving them powerless and cancelling association membership rarely. Harrison and Galloway (2005) mentioned that the code-based frameworks are insufficient as there are chances for professionals to interpret according to their own interests. They suggested to follow 'actionbased ethics with agent-based ethics.' The Global Alliance for Public Relations and Communication Management (GAPRCM) identified these issues in its 'Guiding Principles for the Ethical Practice of Public Relations' and clearly stated, "Ethical performance, not principles, is ultimately what counts" (Harrison \& Galloway, 2005). 


\section{RESPONSIBLE ADVOCACY THEORY}

Curtin and Boynton (2001) mentioned that there are many schools of thought in public relations ethics based on teleological and deontological reasoning such as coordination, advocacy, professionalism, game theory, corporate responsibility, functional approach, discursive approach, contingency, and normative theory.

After surveying several categories of normative justifications of public relations ethics (including enlightened self-interest, social responsibility, advocacy, and two-way symmetry) and finding them falling short, the theory of responsible advocacy was developed to be a significant step towards "providing a universally acceptable philosophy on which standards of ethical public relations practice might be based" (Fitzpatrick \& Gauthier, 2001). The principles of this theory are derived from: 1) some form of utilitarianism; 2) Kant's second formulation of the categorical imperative; 3 ) a version of distributive justice that is not unlike that of Rawls' notion of "justice as fairness" (Danner, 2006).

The three basic principles of responsible advocacy theory are modifications of the four basic principles of health care: Respect for Autonomy, Beneficence, Non-Maleficence, and Justice (Fitzpatrick \& Gauthier, 2001).

This theory is also an updated version of advocacy theory. The advocacy theory is influenced by the social responsibility of the press and persuasion originated from Greek philosophy. The social responsibility theory of the press has suggestions for all communicators including public relations practitioners and it emphasizes on accepting different ideas (Curtin, \& Boynton, 2001). Since Ivy Lee, many practitioners consider social responsibility not only to develop good business sense but also to evaluate other motivations (Seib \& Fitzpatrick, 2006).

As advocacy theory allows the public to decide independently and gives chance to bring voluntary changes in their attitudes and behavior, the supporters of advocacy theory note that ethical persuation is suitable and also necessary to establish the truth in a democratic society based on the culture of freedom of expression (Curtin \& Boynton, 2001). In excellence theory, Grunig (1992) argued that only a two-way symmetrical public relations can guide ethical practice because it gives equal weight to company and public interests. He also mentioned that it uses communication to negotiate with the public, resolve conflict and promote mutual understanding and respect between the organizations and stakeholders.

Fitzpatrick \& Gauthier (2001) clearly stated that the responsible advocacy tries to combine two different ethical roles of public relations practitioners as advocate and social conscience. Public relations professionals have to maintain accountability to the clients or organizations as advocate and also to the public at large as a social conscience. Cameron, Reber and Cropp (2001) strongly recommended that advocacy should be practiced considering the benefits of both sides by motivating both for the good as the practitioners don't advocate a position or course of action for clients and employers only but also for the betterment of the public.

According to Martinson (1994, cited in Fitzpatrick \&Gauthier, 2001), the welfare of other, maintenance of justice, self-dignity, honouring other and the common good should be considered as moral values. Fitzpatrick and Gauthier (2001) suggested the following principles for the theory of responsible advocacy:

1. The comparison of harms and benefits

2. Respect of persons

3. Distributive justice 


\section{THE COMPARISON OF HARMS AND BENEFITS}

Fitzpatrick \& Gauthier (2001) stated that the public relations professionals must carefully think about the harms and benefits of public relations activities. There should not be any harmful contents or they should be minimized in the best possible way and benefits should be ensured. We can get two basic concepts of public relations ethics in this principle: avoidance of harm and ensuring public interest.

\section{Avoidance of Harm}

Avoiding harms is the most important duty of any organizations (Bivins, 1992). In public relations, there should not be any practice of using harmful contents to motivate the target audience. The negative effects of any communication should be considered earlier to avoid harms in public relations. The modern public relations codes also include the paragraph "the member shall not knowingly or intentionally communicate false or misleading information" and "the member shall not corrupt or influence the communication channels and the media" (Walle, 2003). The practice of avoiding harms can also protect the human rights.

\section{Public Interest}

Public interest means serving the whole public, not serving them partially. There are three schools of thought about explaining this concept. Firstly, it is what the majority citizens want. Secondly, it is decided on the basis of standard values whether people like it or not. Thirdly, it is the result of a decision making process based on reality (McQuail, 1992). Popular media serve what the public is interested in. Media in the public interest have four basic characteristics: Diversity, Innovation, Substance, and Independence (Croteau \& Hoynes, 2000). Public relations can ensure public interest if they also have these characteristics.

Kruckeberg and Starck (1988) suggested in their community-building theory that the main goal of public relations "should be to encourage and to promote an understanding of its organizational goals through an interaction with citizens, whose sense of active contribution should be recognized by the organization through implementation and innovation resulting from citizens' contributions, including the organization's acts of social responsibility". Serving community members and their organizations, assisting people to remove isolation, helping individuals to attain security and safety through connection with other members of the community, participating in the community activities, and promoting to build personal friendships are some of the techniques to establish and preserve the sense of community (Kruckeberg and Starck, 1988).

The Public Relations Society of America (PRSA) made its position on public relations clear in the article 2 of the Code that says "A member shall conduct his or her professional life in accord with the public interest" (PRSA, 2016). The official interpretation of this article clarifies interest as "comprising respect for and enforcement of the rights guaranteed by the Constitution of the United States of America" (IML, 2016).

To preserve the public interest, the Canadian Public Relations Society (CPRS) declared that members "shall conduct their professional lives in a manner that does not conflict with the public interest and the dignity of the individual, with respect for the rights of the public as contained in the Constitution of Canada and the Charter of Rights and Freedoms" (CPRS, 2016). According to Walle (2003), the wording about public interest mentioned in the Public Relations Institute of Southern Africa (PRISA) code is very significant as it mentioned that the members "shall respect the public interest and the dignity of the 
individual" (Walle, 2003). The purpose of the corporate public relations is served only if it serves the interest of the people and it will be accepted as ethical practice when public relations services can be accessed by individuals who need it and it ensures public interest (Messina, 2007).

\section{Respect for Persons}

The concept of respect proposed by Kant must fundamentally contain the right of the people to choose anything voluntarily and rationally that reflect their needs and demands (Messina, 2007). As public relations is a form of human communication, human dignity must be guaranteed in every step. Human dignity in public relations is to respect every single individual including the managers, communicators and the audience. Both the members of internal and external public should be treated with respect so that decision-making abilities, choices, and actions (free from deception, manipulation, and coercion) of public relations practitioners are supported and the consumers are also honoured (Fitzpatrick \& Gauthier, 2001). The culture of respecting everyone is possible when public relations practitioners respect their audience by providing adequate true information and the audience respect the professionals for helping the people to choose the best options.

\section{Justice}

Justice is very important to maintain peace and stability in any society. Public relations can fail in long run when justice is not maintained properly. Justice in public relations means establishing the rights of everyone involved in the process. Pain and gain should be shared equally. Loss and profit should be distributed to both the organizations and public. The principle of justice is based on the value of fairness which requires that benefits and burdens are distributed among the affected parties as fairly as possible (Fitzpatrick \& Gauthier, 2001). The distribution is called just when every stakeholder gets what they are supposed to get (Konow, 2001). "Critical judgment is needed to improve skills and to ensure that a profession is responsible and sound" (Van Dyke, 2005). In a just society, people are treated fairly and the decisions are made reasonably. Justice emphasizes on the impartial distribution of common benefits and the sharing the burdens together (Mackie, 2010). Justice should be guaranteed for the people as they really deserve it. (Bivins, 1992).

To ensure appropriate ethical decision making, sometimes these principles function together backing up and complementing each other (Fitzpatrick \& Gauthier, 2001). As the principles can be different in different situations, responsible advocacy must apply the individual ethics of professionals (Cox, 2006).

\section{CONCLUSION}

Ethics is an integral part of public relations. Ethical practices build the trust between internal and external publics of any organizations. Success of any organizations depends on people's trust and confidence gained by ethical practices in public relations. Although different public relations bodies have their own code of ethics, still they need to improve the situation by practical implementation. The findings of the study show that the organizations set different codes of ethics but they lack the strict execution techniques. Only the beautiful words are not enough to establish ethical practices in public relations. The organizations need to enforce obligation to follow the ethics, monitor their public relations activities accordingly, and take exemplary actions against those who are involved in any unethical 
practices. Public relations should not be considered merely a tool of profit making, it must contain the components of responsible advocacy. The proper application of 'Responsible Advocacy Theory' can help the practitioners to establish the universal principles and moral values in public relations. Three major principles mentioned in this theory accommodate maximum ethical issues of public relations. The organizations must not allow any harmful contents and bad practices. Any lies, false or misleading information can easily destroy the image of the organizations. They must ensure public interest for all the stakeholders. Priority should be given to human dignity over all other materialistic gains and benefits. Proper treatment to every single individual involved in this process is must for successful public relations. Finally, justice should be maintained carefully so that everyone benefits from public relations. There is no room for discrimination to gender, race, religion, disability or any other. The organizations can succeed by establishing these important values in public relations.

\section{BIODATA}

Md. Shahidul Haque is an Associate Professor, Dept. of Communication and Journalism at the University of Chittagong, Bangladesh and a PhD candidate at the Universiti Sains Malaysia (USM). His research interest is Islamic public relations, Islamic media ethics and social media. He can be contacted at shahidjr@yahoo.com

Jamilah Hj. Ahmad is a Professor at the School of Communication, Universiti Sains Malaysia (USM). Her area of interest includes public relations, corporate social responsibility (csr), community relations \& communication, corporate communication, communication \& media studies, environmental communication, eLearning, and new media technology. She can be contacted at jahmad@usm.my

\section{REFERENCES}

Abdullah, Z. \& Threadgold, T. (2008). Towards the professionalisation of public relations in Malaysia: Perception management and strategy development. Public Relations Review 34: 285-287

Amila (2016). Making Ethical Decisions: The Six Pillars of Character. Retrieved from http://josephsoninstitute.org/blog/2016/08/18/making-ethical-decisions-six-pillarscharacter/

Baker, S. and Martinson, D.L. (2002), "Out of the red-light district: five principles for ethically proactive public relations", Public Relations Quarterly. 47(3):15. Retrieved from www.questia.com

Bivins, T. H. (1992). A Systems Model for Ethical Decision Making in Public Relations. Public Relations Review, 18(4):365-383

Bowen, S. A. (2007). Ethics and Public Relations - Institute for Public Relations. Retrieved from http://www.instituteforpr.org/ethics-and-public-relations/

Cameron, G. T., Reber B. H. \& Cropp F. (2001). Mythic Battles: Examining the Lawyer-Public Relations Counselor Dynamic. Journal of Public Relations Research 13, 3. P. 208

Canadian Public Relations Society (CPRS). (2016). Code of Professional Standards. Retrieved from http://www.cprs.ca/aboutus/code_ethic.aspx

Croteau, D. \& Hoynes W. (2000). The Business of Media: Corporate Media and the Public Interest. California. Sage Publications

Cox, K. (2006). What is Responsible Advocacy in Public Relations? Retrieved from http://www.trevorcook.typepad.com/weblog/files/pr_kate_coxr.pdf 
Curtin, P. A. \& Boynton, L. A. (2001). Ethics in Public Relations: Theory and Practice. Handbook of Public Relations. California. Sage Publications.

Danner, B. A. (2006). The State of Theory Building in Public Relations Ethics: A Critical Examination. A Thesis Presented to the Graduate School of the University of Florida.

Edgett, R. (2002). Toward an Ethical Framework for Advocacy in Public Relations. Journal of Public Relations Research, 14(1), 1-26

Fisher, C. (2013). Decoding the ethics code: A practical guide for psychologists. Thousand Oaks, CA: SAGE Publications, Inc.

Fitzpatrick, K. \& Gauthier, C. (2001). Toward a Professional Responsibility Theory of Public Relations Ethics. Journal of Mass Media Ethics, 16(2\&3), 193-212

Grunig, L. A., Grunig, J. E. and Dozier, D. M. (2002). Excellent public relations and effective organizations: A study of communication management in three countries. Lea's communication series. Mahwah, NJ: Lawrence Erlbaum.

Grunig, J. E. (Ed.). (1992). Excellence in public relations and communication management. Hillsdale, NJ: Lawrence Erlbaum.

Grunig, J. E. (1993). Public Relations and International Affairs: Effects, Ethics and Responsibility.Journal of International Affairs. 47(1): 138.

Hamdan, A. (2016). Persepsi amalan perhubungan raya kerajaan dari pandangan pengguna - Kajian kes di Sabah. Malaysian Journal of Communication, 32(1)

Harrison, K., \& Galloway, C. (2005). Public relations ethics: A simpler (but not simplistic) approach to the complexities. Prism 3. Retrieved from http://www.prismjournal.org/fileadmin/Praxis/Files/Journal_Files/Issue3/Harrison_ Galloway.pdf

Haque, M. S. \& Ahmad, J. (2016). Islamic Ethics in Public Relations. Journal of Education and Social Sciences. 4:189-193

Idid, S. A. \& Arandas, M. F. (2016). Professional Values, Ethics, and Professionalism of Public Relations Practitioners. Jurnal Komunikasi; Malaysian Journal of Communication. 32(1):287-311. Retrieved from http://www.ukm.my/jkom/journal/pdf_files/2016/V32_1_14.pdf

Idid, S. A. (2005). Institute of Public Relations Malaysia: A historical perspective. Kuala Lumpur, Malaysia: International Islamic University Malaysia.

Interactive Media Lab (IML), University of Florida. (2016). Official Interpretations of the Code. Retrieved from http://iml.jou.ufl.edu/projects/Fall2000/Cregan/interp.html

International Association of Business Communicators (IABC). (2016). IABC Code of Ethics for Professional Communicators. Retrieved from

https://www.iabc.com/about-us/governance/code-of-ethics/

Jalil, S. A. (2009). Growing Public Relations: Lessons from the Past. Kuala Lumpur. IIUM Presss.

Josephson, M. (2001). Definitions in Ethics. Retrieved from https://www.google.com/url?sa=t\&rct=j\&q=\&esrc=s\&source=web\&cd=1\&cad=rja\&u act=8\&ved=0ahUKEwjJx9DBqKnPAhULM48KHbCdAPUQFggcMAA\&url=http\%3A\%2F \%2Fwww.wiley.com\%2Flegacy\%2Fwileychi\%2Fforeman\%2Fsupp\%2F02_definitionine thics.doc\&usg=AFQjCNE_MAVjC2wOwISFGj1DTq60yS7nxQ\&sig2=t8TkA2cVzFaevHE KBnYoyQ\&bvm=bv.133700528,d.c2I

Jung Ki, E. \& Yeon Kim, S. (2010). Ethics Statements of Public Relations Firms: What Do They Say? Journal of Business Ethics. 91, 223-236. Springer. 
Kaur, K. and Shaari, H. (2003). Ethical Practices of Communication Practitioners in Malaysia. UiTM.

King, S. (2012). A Journey Through PR Standards \& Ethics. MEPRA Code of Conduct. Retrieved from https://stephenking2012.wordpress.com/mepra-code-of-conduct/

Konow, J. (2001). Fair and square: the four sides of distributive justice. Journal of Economic Behavior and Organization. 46, 137-164.

Kruckeberg, D. \& Starck, K. (1988). Public relations and community: A reconstructed theory. New York, NY: Praeger.

Lattimore, D., Baskin, O., Suzette, H.T., Toth, E.L. \& Van Leuven, J.K. (2004). Public relations-The profession and the practice. New York: The McGrewHill Companies, Inc.

Mackie, P. (2010). Social justice and social responsibility: Towards a value-base for global public health. Public Health 124, 620-625

McQuail D. (1992). Media Performance: Mass Communication and the Public Interest. California. Sage Publications

Messina, A. (2007). Public relations, the public interest and persuasion: an ethical approach. Journal of Communication Management. 11(1), 29-52. Emerald

Mohamad Khadafi, R., Zainal, M.Z., Mohd Hilmi, H., Kamarudin, N. and Shukri, A. (2016). Perlaksanaan Etika Kerja Islam: Persepsi Masyarakat Terhadap Kewartawanan Islam Media Arus Perdana dan Alternatif. Malaysian Journal of Communication, 32(2), 2941.

Murphy, P. (1991). The limits of symmetry: A game to symmetric and asymmetric public relations. Public Relations Research Annual, 3, 115-132.

Parsons, P. J. (2004). Ethics in Public Relations: A Guide to Best Practice. London. Kogan Page.

Public Relations and Communications Association (PRCA). (2016). Professional Charter and Codes of Conduct. Retrieved from http://www.prca.org.uk/about-us/prstandards/professional-charter-and-codes-conduct

Public Relations Association of America (PRSA). (2016). Member Code of Ethics. Retrieved from

http://www.prsa.org/AboutPRSA/Ethics/CodeEnglish/index.html\#.UwafEfmSzXA

Scopacasa, J. (2016). Ethics in PR - A moral and utilitarian analysis of the PRSA Code. Retrieved from https://www.linkedin.com/pulse/ethics-pr-moral-utilitarian-analysisprsa-code-jessica-scopacasa

Shaari, H. \& Kaur, K. (2012). Standards in the Communication and Media Professions: An Examination of Ethical Codes in Malaysia. (Presented at the Seminar on "Media dan Isu Semasa Serantau," organised by SSIG,Ministry of Information, Communication \& Culture and the Faculty of Communication and Media Studies, Universiti Teknologi MARA.)

Seib, P. \& Fitzpatrick, K. R. (2006). Public Relations Ethics. Belmont, CA. Thomson Wadsworth.

Tuffley, D. (2004). Can Ethics be Taught? School of Information and Communication Technology, Griffith University. Project report, p.4. 
Van Dyke, M. A. (2005). Toward A Theory of Just Communication: A Case Study of NATO, Multinational Public Relations, and Ethical Management of International Conflict. PhD Dissertation. University of Maryland. Retrieved from http://search.proquest.com/docview/304992920/1396B5D71196409DPQ/1?account $\mathrm{id}=44024$

Walle, M. (2003). Commentary: What happened to public responsibility? The lack of society in public relations codes of ethics. PRism 1: 1-5. 